\title{
Association of serum neutrophil gelatinase associated lipocalin (NGAL) levels with preeclampsia
}

\author{
M. Dhivya ${ }^{1}$, Chippy Tess Mathew ${ }^{2 *}$, G. Jeyachandran ${ }^{3}$
}

\begin{abstract}
${ }^{1}$ Department of Biochemistry, KMCH Institute of Health Sciences and Research, Coimbatore, Tamil Nadu, India ${ }^{2}$ Department of Obstetrics and Gynecology, ${ }^{3}$ Department of Biochemistry, PSG Institute of Medical Sciences and Research Coimbatore (affiliated to the Tamil Nadu Dr. MGR Medical University), Tamil Nadu, India
\end{abstract}

Received: 19 November 2018

Accepted: 29 December 2018

\author{
*Correspondence: \\ Dr. Chippy Tess Mathew, \\ E-mail: chippybivin@gmail.com
}

Copyright: (c) the author(s), publisher and licensee Medip Academy. This is an open-access article distributed under the terms of the Creative Commons Attribution Non-Commercial License, which permits unrestricted non-commercial use, distribution, and reproduction in any medium, provided the original work is properly cited.

\begin{abstract}
Background: Preeclampsia is a systemic disorder that affects multiple organs and is characterized by the new onset of hypertension and proteinuria or end-organ dysfunction or both in the second half of pregnancy. NGAL is a 25-KDa protein of the lipocalin family and is considered to be a novel biomarker for ischemic injury. The objective of this study is to compare the levels of serum NGAL in preeclamptic patients and gestational age matched normotensive controls.

Methods: The study design is case control study in which pregnant women with preeclampsia $(n=40)$ are selected as cases. Cases were selected from pregnant women attending OG-OPD and IP satisfying the inclusion criteria and not coming under exclusion criteria. $0.5 \mathrm{ml}$ of blood was collected in vacutainers and was centrifuged at $3500 \mathrm{rpm}$ for 10 minutes. The serum thus separated was aliquoted into smaller plain containers and stored at -20 degree Celsius for analysis. The urine sample was also collected. Controls were also selected from the OP patients.

Results: In present study, the serum NGAL ranged from 40-900ng/ml in cases and from $110-795 \mathrm{ng} / \mathrm{ml}$ in controls. There is no difference in NGAL between cases and control. The correlation coefficients between the NGAL levels and other parameters like maternal age, gestational age, systolic Blood pressure, diastolic Blood pressure, uric acid levels, urine PCR are also not statistically significant.

Conclusions: Serum NGAL levels are not significantly elevated in patients with preeclampsia when compared with the normotensive controls and also there is no significant correlation between serum NGAL levels and other assessed parameters.
\end{abstract}

Keywords: Neutrophil gelatinase associated lipocalin (NGAL), Preeclampsia, Urine PCR

\section{INTRODUCTION}

Hypertensive disorders of pregnancy are a group of complications encountered in up to $10 \%$ of all the pregnancies worldwide. This is one of the leading causes of maternal and perinatal morbidity and mortality. Hypertensive disorders during pregnancy are of four categories: Gestational hypertension, preeclampsiaeclampsia, chronic hypertension (of any cause), chronic hypertension with superimposed preeclampsia. Of this preeclampsia is the most prevalent and most serious form of hypertensive disorder that complicates pregnancy. ${ }^{1,2}$ With mortality due to preeclampsia and its complications estimated to be $50,000-60,000$, it is one of the leading causes of maternal morbidity and mortality. ${ }^{3,4}$ The pathogenesis of preeclampsia is due to an imbalance between the angiogenic and anti-angiogenic factors that leads to the release of inflammatory cytokines. As kidney 
is a highly vascular organ, this endothelial dysfunction results in kidney injury. The development of AKI in pregnancy is termed as pregnancy-related AKI (PRAKI). Studies revealed that preeclampsia and eclampsia accounted for most of PRAKI cases. ${ }^{5}$ There are many biomarker studies for AKI prediction. One of them is serum neutrophil gelatinase-associated lipocalin (NGAL). NGAL is a $25-\mathrm{KDa}$ protein of the lipocalin family. NGAL reduces renal damage by inhibiting cell death and escalating the usual proliferation of kidney tubule cells. So, this protein is up regulated in conditions of kidney injury. Rise of NGAL levels has been recognized in the plasma and urine of animal models of ischemic and nephrotoxic acute kidney injury. Hence, NGAL is considered to be a novel biomarker for ischemic injury. In the study by Patel et al, the study population included the entire spectrum of hypertensive disorders of pregnancy and it was done in North Indian population. ${ }^{6}$ In present study authors have measured the serum NGAL levels in preeclamptic patients in south Indian population and have compared them with control population. If the association between preeclampsia and NGAL levels could be proved in south Indian population also, further studies could be done to use it as a biomarker for preeclampsia thus reducing the morbidity and mortality associated with it.

\section{METHODS}

The study was conducted at PSG Institute of Medical Sciences and Research, Coimbatore. Ethical clearance was obtained from the Institutional Human Ethics Committee.

An informed consent was taken from the patients before sample collection. The study design is case control study in which pregnant women with preeclampsia $(n=40)$ are selected as cases.

The diagnosis of preeclampsia is based on case record description which is based on blood pressure measurements and urine protein creatinine ratio at the time of diagnosis. Cases were selected from pregnant women attending OG-OPD and IP.

Patients satisfying the diagnosis, inclusion criteria and not coming under exclusion criteria were given explanation about this study. If they were willing to participate, the consent forms were filled, and the samples were collected. $5 \mathrm{ml}$ of blood was collected in red topped vacutainers and was centrifuged at 3500rpm for 10 minutes. The serum thus separated was aliquoted into smaller plain containers and stored at-20degree Celsius for analysis. The urine sample was also collected.

Control individuals were also selected from the OG-OPD. Pregnant women fulfilling the control group criteria were requested to participate in the study. If they were willing, the consent forms were filled, and samples were collected from them. Their samples were also processed and stored for analysis.

\section{Inclusion criteria}

Cases

- All pregnant women more than 20 weeks of gestation diagnosed with pre-eclampsia with blood pressure $\geq 140 / 90 \mathrm{~mm}$ of $\mathrm{Hg}$ or urine PCR $\geq 0.3$.

\section{Controls}

- Normal pregnant women more than 20 weeks of gestation without preeclampsia matched for gestational age.

\section{Exclusion criteria}

Subjects with:

- Known chronic hypertension

- Known diabetes mellitus

- Multiple pregnancy

- Any other known medical disorder.

Collection of blood samples: for both cases and controls, blood was collected in red topped serum tube for the estimation of uric acid and urine was also collected for estimation of spot urine protein creatinine ratio. The leftover serum after the estimation of uric acid was transferred to secondary labelled plain tube. This sample was stored at-20-degree Celsius for NGAL assay.

Table 1: Methods used for estimation of biochemical parameters.

\begin{tabular}{|l|l|}
\hline $\begin{array}{l}\text { Parameter } \\
\text { Serum NGAL }\end{array}$ & $\begin{array}{l}\text { Methods used for estimation of } \\
\text { biochemical parameters }\end{array}$ \\
\hline $\begin{array}{l}\text { Serum uric acid } \\
\text { Urine protein } \\
\text { creatinine ratio }\end{array}$ & Enzymatic colorimetric test \\
\hline $\begin{array}{l}\text { Urine protein: } \\
\text { urine creatinine }\end{array}$ & Enzymatic colorimetric method \\
\hline $\begin{array}{l}\text { The ratio of urine protein to urine creatinine is } \\
\text { calculated. }\end{array}$ \\
\hline
\end{tabular}

\section{Statistical analysis}

The data obtained were statistically analyzed using IBM SPSS software version19. The data distribution was displayed by box and whisker plot and bar diagram. To find any statistically significant difference in the distribution of the demographic characteristics and measured parameters independent t-test was used. The dependence of categorical variable was tested with Chi Square test. 
The correlation between quantitative parameters was done using Pearson correlation coefficient and the parameters with statistically significant correlations were further checked by scatter plot analysis. The correlation between quantitative parameters was done using Pearson correlation coefficient and the parameters with statistically significant correlations were further checked by scatter plot analysis.

\section{RESULTS}

The characteristics like maternal age and gestational age are equally distributed in both the cases and controls showing that the two study groups are well matched for these parameters. The socioeconomic status of the two groups is also similar as shown by their distribution.

The distribution of various other parameters including systolic blood pressure, diastolic blood pressure, serum uric acid, urine protein creatinine ratio is also studied. As expected, systolic Blood pressure, diastolic blood pressure, serum uric acid level, urine protein creatinine ratios are higher in cases when compared with the control population.

The values of the t-test done to compare the means of these two groups' maternal age, gestational age, body mass index, socioeconomic status, serum uric acid, urinePCR is shown in Table 3.

This also shows that there is a significant difference between the two groups with respect to parameters like systolic and diastolic blood pressure, body mass index, serum uric acid, urine PCR. It also shows that there is no significant difference between the two groups with regard to maternal age, gestational age of the mother at the time of sampling and socioeconomic status. This implies that the two groups are well matched in these parameters. The serum NGAL level appears to be equally distributed in both the cases and controls as shown in Figure 1.

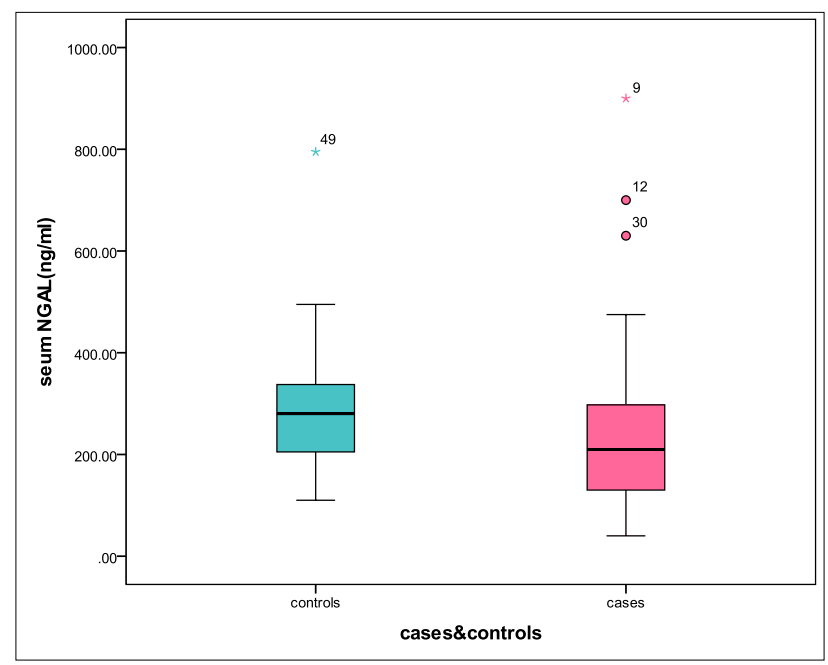

Figure 1: Serum NGAL levels in study groups.

The t-test also does not show any significant difference in NGAL levels in these two groups as shown in Table 2.

There is no significant difference in NGAL level between the two groups. The correlation coefficients between various parameters are shown in Table 3 .

The $r$ values are significant for gestational age and urine PCR, BMI and urine PCR, Uric acid and urine PCR, diastolic Blood pressure and urine PCR, BMI and systolic Blood pressure, BMI and diastolic Blood pressure, diastolic blood pressure and uric acid, systolic Blood pressure and uric acid, but only diastolic Blood pressure and uric acid, systolic Blood pressure and uric acid, uric acid and urine PCR showed positive linear relation.

Table 2: Serum NGAL levels in study groups.

\begin{tabular}{|c|c|c|c|c|c|c|c|c|c|c|}
\hline \multicolumn{11}{|c|}{ Independent samples test } \\
\hline & & \multicolumn{2}{|c|}{$\begin{array}{l}\text { Levene's test } \\
\text { for equality } \\
\text { of variances }\end{array}$} & \multicolumn{7}{|c|}{ t-test for equality of means } \\
\hline & & \multirow[t]{2}{*}{$\mathbf{F}$} & \multirow[t]{2}{*}{ Sig. } & \multirow[t]{2}{*}{$\mathbf{t}$} & \multirow[t]{2}{*}{ df } & \multirow[t]{2}{*}{$\begin{array}{l}\text { Sig. (2- } \\
\text { tailed) }\end{array}$} & \multirow[t]{2}{*}{$\begin{array}{l}\text { Mean } \\
\text { difference }\end{array}$} & \multirow[t]{2}{*}{$\begin{array}{l}\text { Std. error } \\
\text { difference }\end{array}$} & \multicolumn{2}{|c|}{$\begin{array}{l}95 \% \text { Confidence } \\
\text { interval of the } \\
\text { difference }\end{array}$} \\
\hline & & & & & & & & & Lower & Upper \\
\hline \multirow{2}{*}{$\begin{array}{l}\text { Seum } \\
\text { NGAL } \\
\text { levels }\end{array}$} & $\begin{array}{l}\text { Equal } \\
\text { variances } \\
\text { assumed }\end{array}$ & \multirow[t]{2}{*}{3.577} & \multirow[t]{2}{*}{0.062} & 1.063 & 78 & 0.291 & 0.37125 & 0.34935 & -0.32426 & 1.06676 \\
\hline & $\begin{array}{l}\text { Equal } \\
\text { variances not } \\
\text { assumed }\end{array}$ & & & 1.063 & 68.271 & 0.292 & 0.37125 & 0.34935 & -0.32583 & 0.06833 \\
\hline
\end{tabular}


Table 3: Correlation coefficient between various parameters.

\begin{tabular}{|c|c|c|c|c|c|c|c|c|c|}
\hline \multicolumn{10}{|c|}{ Correlations } \\
\hline & & $\begin{array}{l}\text { Maternal } \\
\text { age }\end{array}$ & BMI & $\begin{array}{l}\text { Systolic } \\
\text { BP }\end{array}$ & $\begin{array}{l}\text { Diastolic } \\
\text { BP }\end{array}$ & Gest. age & $\begin{array}{l}\text { Serum } \\
\text { uric acid }\end{array}$ & $\begin{array}{l}\text { Urine } \\
\text { PCR }\end{array}$ & $\begin{array}{l}\text { Serum } \\
\text { NGAL } \\
\text { levels }\end{array}$ \\
\hline \multirow{3}{*}{$\begin{array}{l}\text { Maternal } \\
\text { age }\end{array}$} & & 1 & 0.172 & 0.130 & 0.065 & -0.071 & -0.060 & 0.0002 & -0.073 \\
\hline & & & 0.127 & 0.250 & 0.568 & 0.534 & 0.597 & 0.987 & 0.522 \\
\hline & & 80 & 80 & 80 & 80 & 80 & 80 & 80 & 80 \\
\hline \multirow{3}{*}{ BMI } & & 0.172 & 1 & $0.362^{* *}$ & $0.339^{* *}$ & -0.031 & 0.189 & $0.268^{*}$ & -0.076 \\
\hline & & 0.127 & & 0.001 & 0.002 & 0.787 & 0.093 & 0.016 & 0.502 \\
\hline & & 80 & 80 & 80 & 80 & 80 & 80 & 80 & 80 \\
\hline \multirow{3}{*}{$\begin{array}{l}\text { Systolic } \\
\text { BP }\end{array}$} & & 0.130 & $0.362^{* *}$ & 1 & $0.902^{* *}$ & -0.084 & $0.549^{* *}$ & $0.539^{* *}$ & -0.176 \\
\hline & & 0.250 & 0.001 & & 0.000 & 0.460 & 0.000 & 0.000 & 0.119 \\
\hline & & 80 & 80 & 80 & 80 & 80 & 80 & 80 & 80 \\
\hline \multirow{3}{*}{$\begin{array}{l}\text { Diastolic } \\
\text { BP }\end{array}$} & & 0.065 & $0.339^{* *}$ & $0.902^{* *}$ & 1 & -0.127 & $0.628^{* *}$ & $0.575^{* *}$ & -0.066 \\
\hline & Sig. (2-tailed) & 0.568 & 0.002 & 0.000 & & 0.263 & 0.000 & 0.000 & 0.563 \\
\hline & $\mathrm{N}$ & 80 & 80 & 80 & 80 & 80 & 80 & 80 & 80 \\
\hline \multirow{3}{*}{ Gest. age } & $\begin{array}{l}\text { Pearson } \\
\text { correlation }\end{array}$ & -0.071 & -0.031 & -0.084 & -0.127 & 1 & -0.085 & $-0.274^{*}$ & -0.117 \\
\hline & Sig. (2-tailed) & 0.534 & 0.787 & 0.460 & 0.263 & & 0.453 & 0.014 & 0.300 \\
\hline & $\mathrm{N}$ & 80 & 80 & 80 & 80 & 80 & 80 & 80 & 80 \\
\hline \multirow{3}{*}{$\begin{array}{l}\text { Serum } \\
\text { uric acid }\end{array}$} & $\begin{array}{l}\text { Pearson } \\
\text { correlation }\end{array}$ & -0.060 & 0.189 & $0.549^{* *}$ & $0.628^{* * *}$ & -0.085 & 1 & $0.626^{* *}$ & 0.129 \\
\hline & Sig. (2-tailed) & 0.597 & 0.093 & 0.000 & 0.000 & 0.453 & & 0.000 & 0.254 \\
\hline & $\mathrm{N}$ & 80 & 80 & 80 & 80 & 80 & 80 & 80 & 80 \\
\hline \multirow{3}{*}{$\begin{array}{l}\text { Urine } \\
\text { PCR }\end{array}$} & $\begin{array}{l}\text { Pearson } \\
\text { Correlation }\end{array}$ & 0.002 & $0.268^{*}$ & $0.539^{* *}$ & $0.575^{* *}$ & $-0.274^{*}$ & $0.626^{* *}$ & 1 & 0.107 \\
\hline & Sig. (2-tailed) & 0.987 & 0.016 & 0.000 & 0.000 & 0.014 & 0.000 & & 0.343 \\
\hline & $\mathrm{N}$ & 80 & 80 & 80 & 80 & 80 & 80 & 80 & 80 \\
\hline \multirow{3}{*}{$\begin{array}{l}\text { Seum } \\
\text { NGAL } \\
\text { levels }\end{array}$} & $\begin{array}{l}\text { Pearson } \\
\text { correlation }\end{array}$ & -0.073 & -0.076 & -0.176 & -0.066 & -0.117 & 0.129 & 0.107 & 1 \\
\hline & Sig. (2-tailed) & 0.522 & 0.502 & 0.119 & 0.563 & 0.300 & 0.254 & 0.343 & \\
\hline & $\mathrm{N}$ & 80 & 80 & 80 & 80 & 80 & 80 & 80 & 80 \\
\hline
\end{tabular}

** Correlation is significant at the 0.01 level (2-tailed); *Correlation is significant at the 0.05 level (2-tailed).

\section{DISCUSSION}

Preeclampsia is a systemic disorder that affects multiple organs and is characterized by the new onset of hypertension and proteinuria or end-organ dysfunction or both in the second half of pregnancy. The acute complications associated with preeclampsia include eclampsia, renal failure, stroke, permanent neurologic impairment, cardiac dysfunction or arrest, respiratory compromise, coagulopathy and liver failure. ${ }^{7}$ The diagnosis of preeclampsia is based on the increase in blood pressure in a previously normal patient on two occasions 4hours apart after 20 weeks of gestation or the presence of proteinuria $(>300 \mathrm{mg} /$ day $)$. Preeclampsia can be mild/severe. Severe preeclampsia is characterized by more substantial blood pressure elevations (systolic $\geq 160 \mathrm{~mm} \mathrm{Hg}$, diastolic $\geq 110 \mathrm{~mm} \mathrm{Hg}$ ), a greater degree of proteinuria ( $>5 \mathrm{~g} / 24$ hours) and the presence of symptoms associated with target organ involvement. ${ }^{8}$ Xiao et al, evaluated a combination of biomarkers for diagnosing AKI with considerable accuracy in preeclampsia. ${ }^{9}$ Serum cystatin $\mathrm{C}$, urine retinol-binding protein, urine NGAL and urine kidney injury molecule-1 levels in the preeclampsia group were higher than the normal pregnancy group. When these markers were combined, the sensitivity and specificity for diagnosing AKI were almost 100\%. Patel et al, reported that NGAL level was significantly associated with serum creatinine in the Indian pregnant population with hypertension. ${ }^{6}$ Serum NGAL level in oliguric patients was significantly higher compared with non-oliguric patients. Serum NGAL level also had a positive correlation with disease severity including blood pressure level, blood urea nitrogen (Bun), serum creatinine, and serum uric acid in hypertensive pregnant patients. The distribution of the maternal age and gestational age are similar in the cases and the control population and their t-values are also not significant. This shows that the two groups are well matched in these characteristics. The two groups showed different distributions in case of parameters like systolic Blood pressure, diastolic Blood pressure, serum uric acid levels, urine protein creatinine ratio. The t-values are also 
significant in these parameters among the two groups. This is expected because the diagnosis of preeclampsia is based on the systolic Blood pressure, diastolic Blood pressure, serum uric acid levels, urine protein creatinine ratio and the division of the study population into two groups is based on these parameters.

When the correlation between various parameters are studied using Pearson correlation coefficient, the resulting $\mathrm{R}$-values are significant for gestational age and urine PCR, BMI and urine PCR, uric acid and urine PCR, diastolic Blood pressure and urine PCR, BMI and systolic Blood pressure, BMI and diastolic blood pressure, diastolic Blood pressure and uric acid, systolic blood pressure and uric acid. In consistent with the studies done by Aliyu et al, Bodnar et al, in this study, the distribution of body mass index is in the higher range in women with preeclampsia when compared with the normotensive controls. The t-test value $(p=0.001)$ obtained by comparing the means of the two groups is also significant. This finding suggests that increased body mass index poses a threat for developing preeclampsia. Pandinis D et al, and Lou et al, have shown in their study that there is a significant correlation between serum NGAL levels and body mass index. ${ }^{10,11}$ But, in present study no significant correlation is found between serum NGAL levels and body mass index

In the studies done by Anna et al, Simonazzi et al, Patel et al, to find out the correlation between serum NGAL levels and preeclampsia, the two study groups, cases and controls were matched for body mass index as elevated BMI was considered as a confounding factor. ${ }^{6,12,13}$ But in present study, the cases and controls are not matched for BMI. Since NGAL is also produced by adipocytes, a positive correlation was expected between serum NGAL levels and the body mass index. But the Pearson correlation coefficient between NGAL and BMI is not significant to prove any correlation $(\mathrm{r}=0.076, \mathrm{p}=0.502)$. This suggests that obesity and preeclampsia are correlated but not obesity and NGAL. So, it can be said that obesity may not be a confounding factor in estimation of serum NGAL levels and the pre-pregnancy $\mathrm{BMI}$ rather than the BMI at the time of sampling could be considered. In present study, serum uric acid level was also significantly higher in the preeclamptic women than in the normotensive controls as indicated by t-test value $(\mathrm{p}=0.00)$.Since estrogen is a uricosuric agent serum uric acid levels fall by $25-35 \%$ in pregnant women. ${ }^{14}$ Apart from estrogen, expanded plasma volume, elevated GFR also leads to decrease in uric acid levels in pregnancy. ${ }^{14}$ In women with preeclampsia, hyperuricemia is a regular finding. Impaired renal function has been considered the causative factor for hyperuricemia in preeclampsia.

In the study done by Pereira et al, to evaluate the use of uric acid as a marker of severity of pre-eclampsia, they were able to find significant correlations between uric acid and systolic blood pressure. ${ }^{15}$ In a similar study done by Pramanik et al, to assess whether serum uric acid can be used as a biochemical indicator or not in preeclamptic patients, they were able to demonstrate a positive correlation between serum uric acid levels and elevated systolic pressure and diastolic blood pressure. ${ }^{16}$ Consistent with these findings, in this study, a significant positive correlation is found between serum uric acid levels and systolic BP $(r=0.549, p=0.00)$. A linear relation is found between these two parameters by scatter plot analysis.

Nischinta et al, have done a study to find out the correlation between 24-hour urine protein, spot urine protein creatinine ratio and uric acid. ${ }^{17}$ They were able to demonstrate a positive and statistically significant correlation between serum uric acid level and urine protein creatinine ratio. Similarly, in this study, a statistically significant positive correlation is found between serum uric acid level and spot urine protein creatinine ratio $(\mathrm{r}=0.626, \mathrm{p}=0.00)$.

In the study done by Anna et al, they have concluded that serum NGAL levels were higher in the preeclamptic women in all three trimesters when compared with the control population. ${ }^{12}$ Although Kim et al, have also demonstrated a statistically significant difference in NGAL level between the two groups, the range of NGAL levels in the two groups were similar $(66.1-575.4 \mathrm{ng} / \mathrm{ml}$ in cases and 7.0-669.7 $\mathrm{ng} / \mathrm{ml}$ in controls). ${ }^{18}$

Simonazzi et al, have done a cross sectional case control study to compare the serum and urinary NGAL levels in preeclampsia and in normal pregnancies and also to find out the correlation between NGAL and blood pressure, creatinine, uric acid,24-hour proteinuria. ${ }^{13}$ They could not demonstrate a statistically significant difference in the NGAL levels between the two populations. They were not able to demonstrate a positive correlation between NGAL and uric acid, creatinine, blood pressure. In a study done by Dogan et al, to evaluate the serum NGAL levels and plasma Nitric oxide in preeclamptic women and normal controls, the investigators were not able to find a statistically significant difference in the NGAL levels between the two groups. ${ }^{19}$ But they were able to find a statistically significant correlation between NGAL levels and BMI.

In present study, the serum NGAL ranged from 40$900 \mathrm{ng} / \mathrm{ml}$ in cases and from $110-795 \mathrm{ng} / \mathrm{ml}$ in controls. The distribution range of NGAL in cases covers the distribution range of controls. This shows that there is no difference in NGAL between cases and control. The correlation coefficients between the NGAL levels and other parameters like maternal age, gestational age, systolic Blood pressure, diastolic Blood pressure, uric acid levels, urine PCR are also not statistically significant.

These findings of this study are consistent with those of Simonazi et al, and Dogen et al, and contrast from the findings of Anna et al, Kim et al. ${ }^{12,13,17,19}$ 


\section{CONCLUSION}

Serum NGAL levels are not significantly elevated in patients with preeclampsia when compared with the normotensive controls. There is no significant correlation between serum NGAL levels and systolic Blood pressure, diastolic Blood pressure, serum uric acid, urine PCR, maternal age and gestational age.

\section{Funding: PSG PRIME}

Conflict of interest: None declared

Ethical approval: The study was approved by IHEC PSGIMSR

\section{REFERENCES}

1. Lindheimer, Taler SJ, Cunningham. Hypertension in pregnancy. J Am Soc Hypertension. 2010;4:68-78.

2. American College of Obstetricians and Gynecologists. Diagnosis and management of preeclampsia and eclampsia: ACOG practice bulletin, No. 33. Int J Gynaecol Obstet. 2002;77:675.

3. World Health organization. The World Health report: 2005: make every mother and child count. Geneva: WHO;2005.

4. Daley L. Maternal mortality associated with hypertensive disorders of pregnancy in Africa, Asia, Latin America and the Carribean. $\mathrm{Br} \mathrm{J}$ Obstet Gynecol. 1992;99:547-3.

5. Siribamrungwong $\mathrm{M}$, Chinudomwong P. Relation between acute kidney injury and pregnancy-related factors. J Acute Dis. 2016;5(1):22-8.

6. Patel ML, Sachan R, Gangwar R, Sachan P, Natu SM. Correlation of serum neutrophil gelatinaseassociated lipocalin with acute kidney injury in hypertensive disorders of pregnancy. Int $\mathbf{J}$ Nephrol Renov Dis. 2013;6:181-6.

7. Wallis AB, Saftlas AF, Hsia J, Atrash HK. Secular trends in the rates of preeclampsia, eclampsia, and gestational hypertension, United States, 1987-2004. Am J Hypertens. 2008;21(5):521-6.

8. Machado S, Figueiredo N, Borges A, Pais MS, Freitas L, Moura P, et al. Acute kidney injury in pregnancy: a clinical challenge. J Nephrol. 2012;25(01):19-30.

9. Xiao J, Niu J, Ye X, Yu Q, Gu Y. Combined biomarkers evaluation for diagnosing kidney injury in preeclampsia. Hypertension pregnancy. 2013;32(4):439-9.

10. Panidis D, Tziomalos K. The effects of obesity and polycystic ovary syndrome on serum lipocalin-2 levels: a cross-sectional study. Reprod Biol Endocrinol. 2010;8:151.

11. Lou Y1, Wu C1, Wu M1, Xie C, Ren L. The changes of neutrophil gelatinase-associated lipocalin in plasma and its expression in adipose tissue in pregnant women with gestational diabetes. Diab Res Clin Pract. 2014;104(1):136-42.

12. D'anna R, Baviera G, Giordano D, Todarello G, Russo S, Recupero S, et al. Neutrophil gelatinaseassociated lipocalin serum evaluation through normal pregnancy and in pregnancies complicated by preeclampsia. Acta obstet Gynecol Scandinav. 2010;89(2):275-8.

13. Simonazzi G, Capelli I, Curti A, Comai G, Rizzo N, La Manna G. Serum and urinary neutrophil gelatinase-associated lipocalin monitoring in normal pregnancy versus pregnancies complicated by preeclampsia. In Vivo. 2015;29(1):117-21.

14. Quinones Galvan A, Natali A, Baldi SI, Frascerra SI, Sanna GI, Ciociaro DE, et al. Effect of insulin on uric acid excretion in humans. Am $\mathbf{J}$ Physiol Endocrinol Metabol. 1995;268(1):E1-5.

15. Pereira KN, Knoppka CK, da Silva JE. Association between uric acid and severity of pre-eclampsia. Clin Lab. 2014;60(2):309-14.

16. Pramanik T, Khatiwada B, Pradhan P. Serum uric acid level in normal pregnant and preeclamptic ladies: a comparative study. Nepal Med Coll J 2014; 16(1):30-2.

17. Nischintha $S$, Pallavee $P$, Ghose $S$. Correlation between 24-h urine protein, spot urine protein/creatinine ratio, and serum uric acid and their association with fetomaternal outcomes in preeclamptic women. J Natural Sci Biol Med. 2014;5(2):255.

18. Kim SM, Park JS, Norwitz ER, Jung HJ, Kim BJ, Park CW, et al. Circulating levels of neutrophil gelatinase-associated lipocalin (NGAL) correlate with the presence and severity of preeclampsia. Reprod Sci. 2013;20(9):1083-9.

19. Dogan N1, Yildirmaki S, Mihmanli V, Vardar M, Ozbanazi YG, Cakmak M, et al. Serum neutrophil gelatinase associated lipocalin and plasma nitric oxide levels in healthy and preeclamptic pregnants. Clin Exp Obstet Gynecol. 2014;41(6):700-3.

Cite this article as: Dhivya M, Mathew CT, Jeyachandran G. Association of serum neutrophil gelatinase associated lipocalin (NGAL) levels with preeclampsia. Int J Reprod Contracept Obstet Gynecol 2019;8:513-8. 